\title{
EFFECT OF REPEATED HIGH DOSE PROPHYLAXIS WITH AMOXYCILLIN ON THE RESIDENT ORAL FLORA OF ADULT VOLUNTEERS
}

\author{
A. J. Woodman, Joan Vidic*, H. N. Newman* and P. D. Marsh' \\ HMS Dolphin, Gosport, Hampshire, * Departments of Clinical Pathology and \\ Immunology and of Periodontology, Institute of Dental Surgery, Eastman Dental \\ Hospital, London WCIX 8LD, and †Pathogenic Microbes Research Laboratory, \\ PHLS Centre for Applied Microbiology and Research, Porton Down, Salisbury SP4 \\ $O J G$
}

SummaRy. Healthy adult volunteers received either single or repeated 3-g doses of amoxycillin by mouth at weekly intervals on three occasions. The salivary flora of each volunteer was monitored before, during and up to 11 weeks after the final dose of antibiotic. Viable counts of anaerobic bacteria, streptococci and streptococci resistant to amoxycillin $2 \mathrm{mg} / \mathrm{L}$ and $40 \mathrm{mg} / \mathrm{L}$ were determined in samples of saliva. All 20 volunteers harboured low numbers of streptococci resistant to amoxycillin $2 \mathrm{mg} / \mathrm{L}$ (mean count $=6.57 \times 10^{3} \mathrm{cfu} / \mathrm{ml}$ of saliva) before administration of the antibiotic; much lower carriage rates $(45 \%)$ were observed for bacteria resistant to amoxycillin $40 \mathrm{mg} / \mathrm{L}$ (mean count $=116 \mathrm{cfu} / \mathrm{ml}$ of saliva). Each dose of amoxycillin had a rapid but transient effect on the numbers of salivary bacteria. A placebo lacking the antibiotic had no effect. A single 3-g dose of amoxycillin had little or no effect on the numbers of resistant streptococci and, therefore, it was concluded that in patients at risk of infective endocarditis a second prophylactic dose would not be invalidated. The numbers of resistant streptococci increased significantly after the second and third doses of amoxycillin, and persisted for 4-7 weeks. Consequently, in at-risk patients requiring repeated dental procedures liable to produce bacteraemia, either alternative antibiotic regimens should be used each time or intervals of at least 4 weeks should be left between treatment sessions.

\section{INTRODUCTION}

Transient bacteraemia commonly follows dental procedures that produce bleeding from oral tissues. These procedures include extractions, scaling and periodontal surgery. Consequently, patients at risk of infective endocarditis receive antibiotic prophylaxis before such treatment (Cawson, 1981 and 1983) to kill any bacteria that gain entry to the blood stream. Streptococci are frequently isolated from patients with infective endocarditis (Lowes et al., 1980; Moulsdale, Eykyn and Phillips 1980) and the 
antibiotic cover should provide serum concentrations that are bactericidal to these organisms. In view of the discomfort and lack of patient co-operation frequently associated with parenteral administration (Holbrook, Willey and Shaw, 1983), the development of effective oral antibiotic prophylaxis has been a major objective.

Of particular relevance in this respect is the recent recommendation of the working party of the British Society for Antimicrobial Chemotherapy (1982) of a single 3-g oral dose of amoxycillin, $1 \mathrm{~h}$ before treatment, in patients not allergic to the penicillin group of antibiotics. In some patients, notably those with chronic inflammatory periodontal disease, repeated procedures over several sessions are required to achieve dental health. Patients at risk of infective endocarditis require antibiotic cover at each session. However, the numbers of resistant bacteria increase after the repeated administration of the same antibiotic (Tozer, Boutflower and Gillespie, 1966) and it is, therefore, now accepted that at least 1 month should elapse between treatments with the same drug.

One of the advantages of prophylaxis with a single high dose of amoxycillin compared with other antibiotics is that serum levels of the former remain high only for the critical period of 8-10 h after dental procedures (Durack and Petersdorf, 1973; Pelletier, Durack and Petersdorf, 1975; Shanson, Ashford and Singh, 1980) and would be expected to have only a minor effect on the resident bacterial flora. Indeed, a single 3-g dose of amoxycillin was found to cause no change in the antibiotic sensitivity of oral streptococci (Oakley, Perez and Darrell, 1981), although repeated doses over four successive days markedly increased the numbers of resistant bacteria (Oakley and Darrell, 1982). Consequently, in view of the frequent need for patients to have dental treatment over several visits, we have studied the effect of a single and of repeated 3-g doses of amoxycillin administered at weekly intervals on the emergence of resistant streptococci in the mouths of volunteers. The numbers of bacteria resistant to amoxycillin before administration of the drug were also determined.

\section{MATERIALS AND METHODS}

Subjects. Twenty healthy adult volunteers (mean age 33.8 years) were randomised into two groups. Group A (three female and seven male subjects; mean age 34.8 years) received a single 3-g oral dose of amoxycillin while Group B (ten male subjects; mean age 32.8 years) received three doses at weekly intervals. The antibiotic was provided in a sachet (Amoxil ${ }^{\circledR}$, Bencard, Brentford, England) and administered as a flavoured suspension in $55 \mathrm{ml}$ of water. Sachets with the same batch number were used throughout the study. A third group (Group P) of four male subjects (mean age 36.8 years) were randomly selected from Group A 3 months after administration of their single dose of antibiotic and were given three oral doses of a placebo at weekly intervals. The placebo contained no antibiotic but was otherwise similar in colour, consistency and taste to Amoxil ${ }^{\circledR}$ suspensions given to Groups A and B. None of the subjects had received penicillin or any other antibiotic for at least 3 months before the start of the experimental period. All volunteers gave their informed consent to participate in the study. Any side-effects experienced by the volunteers were recorded.

Saliva samples and bacteriological analysis. Stimulated whole saliva was collected in a sterile container at the same time of day from each subject. Stimulation was induced by chewing on dental ribbon wax for $3 \mathrm{~min}$. The bacteria present in each salivary sample were dispersed by vortex mixing, serially diluted in nutrient broth, and portions plated on Blood Agar (Oxoid) for viable counts of anaerobic bacteria, and on Mitis-Salivarius (MS) Agar (Oxoid) to determine the numbers of streptococci present. Further portions were plated on MS agar, containing amoxycillin $2 \mathrm{mg} / \mathrm{L}$ and $40 \mathrm{mg} / \mathrm{L}$ respectively, to enable resistant streptococci and those resistant to peak serum levels to be enumerated. All plates were incubated anaerobically for $72 \mathrm{~h}$ at $37^{\circ} \mathrm{C}$ in an atmosphere of $\mathrm{CO}_{2} 10 \%$ in $\mathrm{H}_{2}$. Bacteria isolated on MS agar were confirmed as streptococci 
on the basis of their colonial morphology, positive reaction with Gram's stain and negative catalase activity. Representative colonies from the MS agar supplemented with amoxycillin 40 $\mathrm{mg} / \mathrm{L}$, were identified by the criteria of Hardie and Bowden (1976).

Carriage of amoxycillin-resistant bacteria. To provide a base-line for the study of the effects of amoxycillin on the resident oral flora and to determine the carriage of amoxycillin-resistant bacteria in this group of individuals, three samples of saliva were taken from subjects in Groups $A$ and $B 7$ days, 4 days and $30 \mathrm{~min}$ before administration of the antibiotic. The saliva samples were processed as described above.

Evaluation of the effect of a single and of repeated 3-g doses of amoxycillin on the resident oral flora. In subjects in group A, who received a single dose, saliva samples were taken $5 \mathrm{~h}$ after and on days $3,7,10,14,17$ and 21 after administration of the antibiotic. In subjects in Group B, samples were taken $5 \mathrm{~h}$ after and 4 and 7 days after each of the three administrations of a single dose of antibiotic at weekly intervals. Saliva samples were also taken on days 4, 7, 14, 21, 28, 49 and 77 after the third and final dose of amoxycillin. Samples from subjects in Group P were taken $5 \mathrm{~h}$ after and on days 4 and 7 after each dose of placebo. Saliva samples were processed as described above. Statistical comparison of the results was performed with Student's $t$-test.

\section{RESULTS}

\section{Carriage of amoxycillin-resistant bacteria}

Two or three samples of saliva were taken before antibiotic administration to establish base-line levels for the total numbers of salivary bacteria and the carriage of amoxycillin-resistant streptococci by each subject. Total numbers of anaerobic bacteria in saliva varied both between individuals (range $9.33 \times 10^{7}-6.47 \times 10^{9}$ $\mathrm{cfu} / \mathrm{ml}$; mean count $=5.82 \times 10^{8} \mathrm{cfu} / \mathrm{ml}$ ) and between samples from the same individual. All 20 subjects of Groups A and B harboured bacteria able to grow on the streptococci-selective MS medium containing amoxycillin $2 \mathrm{mg} / \mathrm{L}$ although, in two subjects, resistant bacteria were isolated from only one third and two thirds of the samples, respectively. The mean count of resistant bacteria in these 20 subjects was $6.57 \times 10^{3} \mathrm{cfu} / \mathrm{ml}$ (median count $=5 \cdot 70 \times 10^{3} \mathrm{cfu} / \mathrm{ml}$ ) but the range between individuals was wide $\left(17 \mathrm{cfu} / \mathrm{ml}-2 \cdot 50 \times 10^{6} \mathrm{cfu} / \mathrm{ml}\right)$. Bacteria growing on MS plates containing amoxycillin $40 \mathrm{mg} / \mathrm{L}$ were isolated much less frequently (from only 9 of 20 subjects) and in much lower numbers (mean viable count from positive samples $=116 \mathrm{cfu} / \mathrm{ml}$; range $=0-2 \cdot 36 \times 10^{3} \mathrm{cfu} / \mathrm{ml}$ ). In all subjects, if the results were expressed in proportional terms, the numbers of resistant bacteria would be far less than $1 \%$ of the total cultivable flora.

\section{Effect of a single 3-g dose of amoxycillin on the resident oral flora}

The results of the bacteriological studies of the 10 subjects (Group A) before and after the administration of a single 3-g dose of amoxycillin are shown in fig. 1. Immediately after taking the antibiotic, total numbers of resistant and sensitive streptococci decreased significantly $(\mathrm{p}<0.001)$. The numbers of streptococci, including those resistant to amoxycillin $2 \mathrm{mg} / \mathrm{L}$, rapidly rose to levels greater than those recorded during the base-line studies. This rise, however, was not statistically significant and, after 3 weeks, the counts of these streptococci returned to base-line values. In contrast, the frequency of isolation and the total numbers of bacteria resistant to amoxycillin $40 \mathrm{mg} / \mathrm{L}$ fell below the values found before antibiotic administration. 


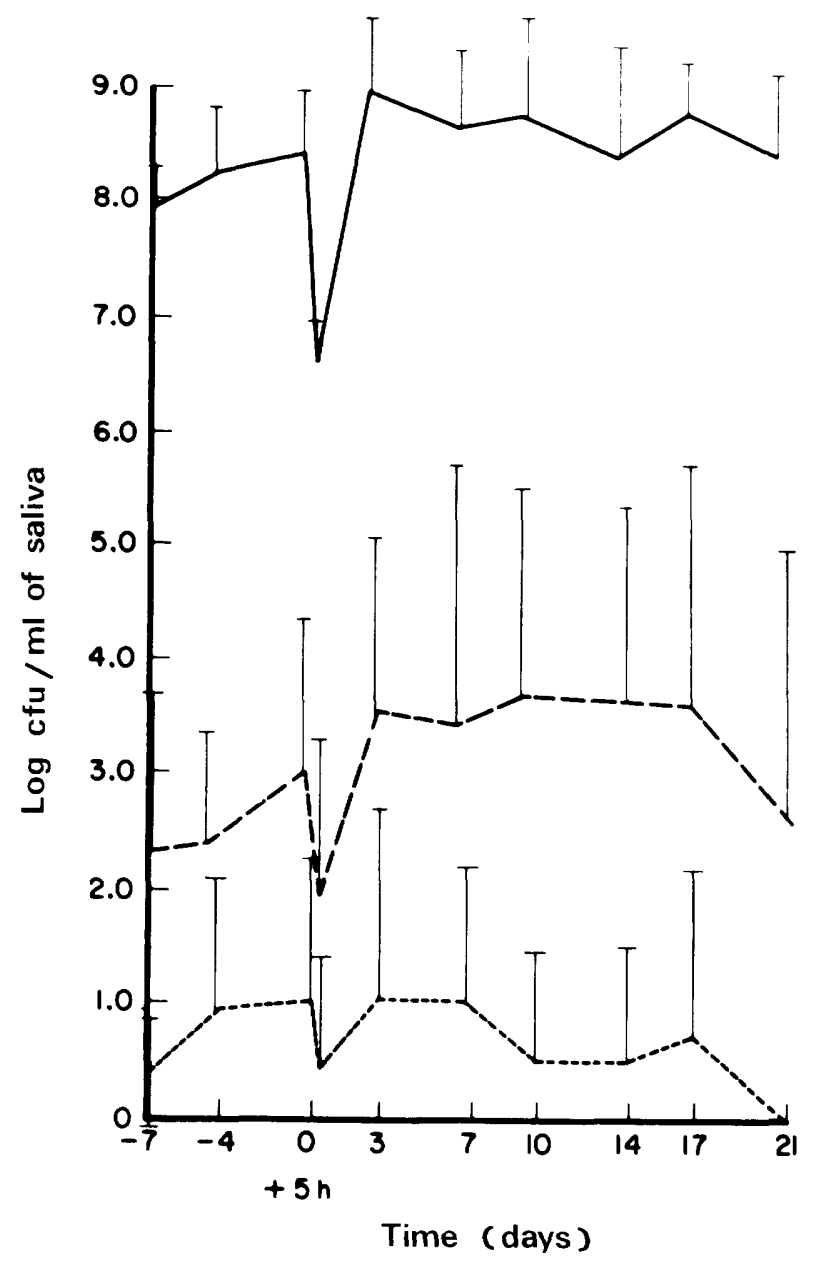

FIG. 1.-Mean log count (cfu/ml) of streptococci ($(--)$ and $40 \mathrm{mg} / \mathrm{L}(-\ldots+\ldots)$ in the saliva of 10 subjects who received a single $3-\mathrm{g}$ oral dose of amoxycillin on day 0 .

Effect of three 3-g doses of amoxycillin, taken at weekly intervals, on the resident oral flora

The results of the bacteriological studies of the 10 subjects comprising Group B are shown in fig. 2 (a) and (b). As before, the total numbers of bacteria, including resistant and sensitive streptococci, fell significantly $(p<0.001)$ with each dose of amoxycillin. The flora recovered quickly on each occasion and there was no statistically significant difference between the counts of the total anaerobic or streptococcal flora before and after the three doses of amoxycillin. However, after the second and third doses of antibiotic, numbers of streptococci resistant to amoxycillin $2 \mathrm{mg} / \mathrm{L}$ and $40 \mathrm{mg} / \mathrm{L}$ increased markedly $(\mathrm{p}<0.001)$. Counts of streptococci resistant to $2 \mathrm{mg} / \mathrm{L}$ and 40 $\mathrm{mg} / \mathrm{L}$ amoxycillin remained at a statistically significantly higher level for, on average, 28 and 21 days, respectively, although these times varied between individuals. For 


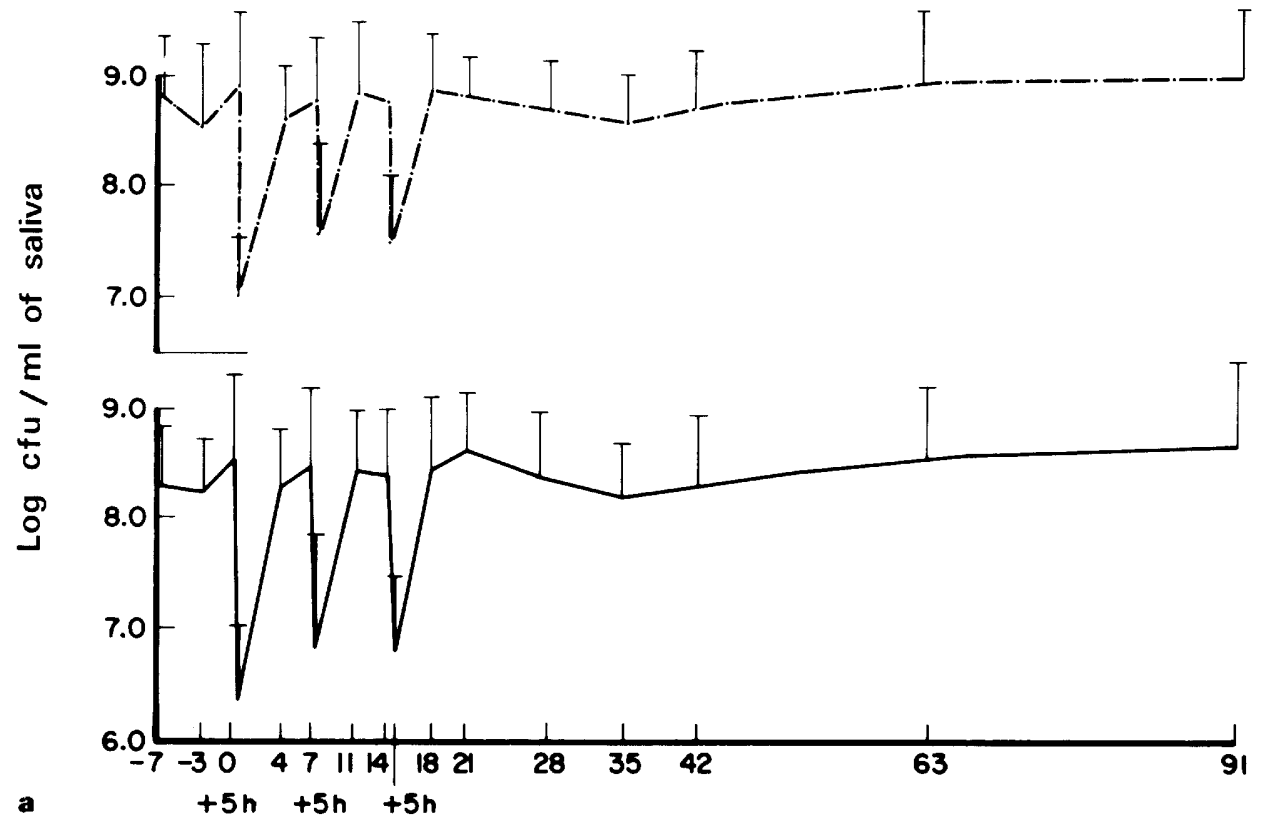

Time (days)

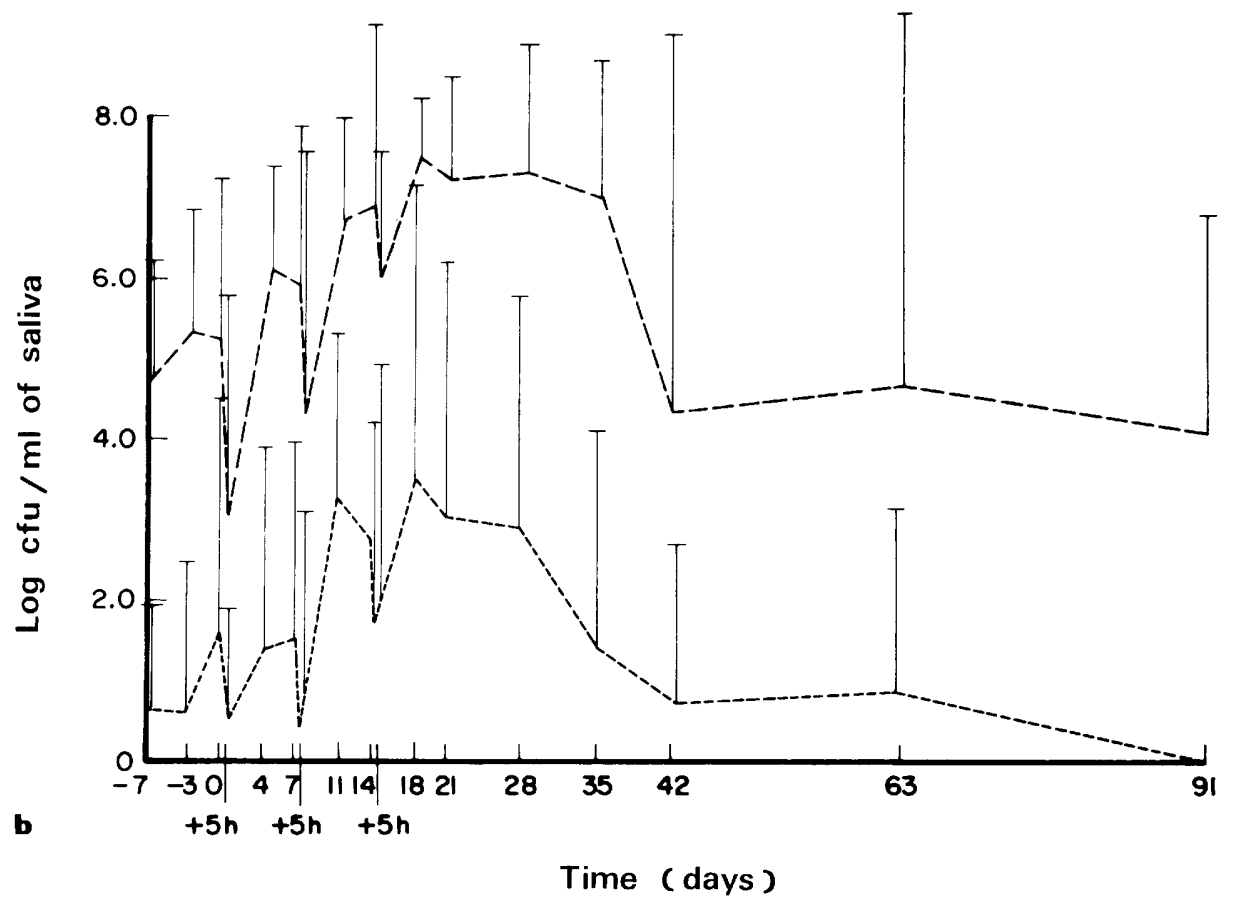

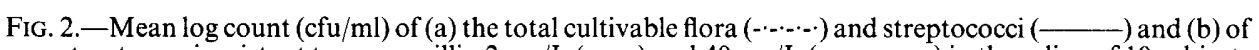
streptococci resistant to amoxycillin $2 \mathrm{mg} / \mathrm{L}(--)$ and $\left.40 \mathrm{mg} / \mathrm{L}(\ldots . .-)^{-.-}\right)$in the saliva of 10 subjects who received a 3-g oral dose of amoxycillin on days 0,7 and 14. 
example, in two subjects the numbers of resistant bacteria did not return to base-line levels for 7 weeks. Furthermore, by 11 weeks after the third dose, no streptococci resistant to amoxycillin $40 \mathrm{mg} / \mathrm{L}$ could be isolated from the saliva of any of the volunteers. The mean count of bacteria resistant to amoxycillin $40 \mathrm{mg} / \mathrm{L}$ up to and including the first sample in which they were not detected was $373 \mathrm{cfu} / \mathrm{ml}$ of saliva (median count $=383 \mathrm{cfu} / \mathrm{ml}$; range $=0-5.82 \times 10^{4} \mathrm{cfu} / \mathrm{ml}$; peak concentration $=1 \cdot 10 \times 10^{7} \mathrm{cfu} / \mathrm{ml}$ in one subject 4 days after the third dose).

\section{Effect of three doses of a placebo on the resident flora}

The results for the four subjects in Group P are shown in fig. 3, which also serves to illustrate the fluctuating nature of the numbers of anaerobic bacteria in saliva. The placebo had no statistically significant effect on any component of the flora that was measured in this study.

\section{Identification of bacteria resistant to amoxycillin $40 \mathrm{mg} / \mathrm{L}$}

Organisms isolated on MS agar supplemented with amoxycillin $40 \mathrm{mg} / \mathrm{L}$ have been identified as Streptococcus mutans and S. sanguis. This work is still in progress and will form the basis of a separate communication.

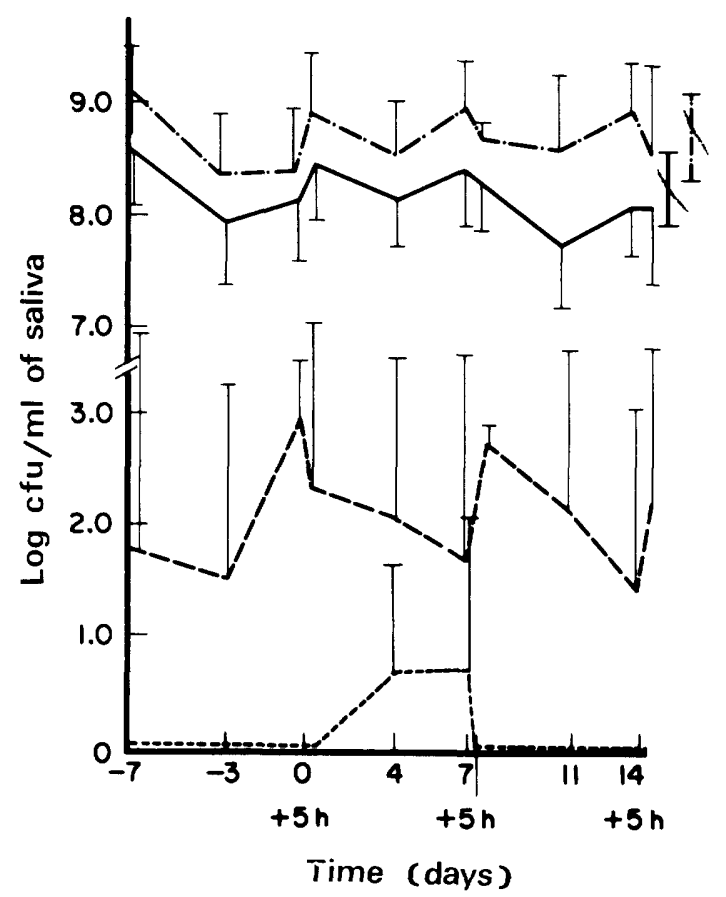

FIG. 3.-Mean log count (cfu/ml) of the total cultivable flora (-·--·), streptococci ( $-\longrightarrow$ ), and streptococci resistant to amoxycillin $2 \mathrm{mg} / \mathrm{L}(--)$ and $40 \mathrm{mg} / \mathrm{L}(-\ldots .-)$ in the saliva of four subjects who received a placebo on days 0,7 and 14 . 


\section{DisCUSSION}

The longitudinal nature of this study precluded the use of dental plaque for bacteriological analysis. Sequential samples taken at short intervals were necessary to follow the changes in the composition of the resident oral flora before and after prophylaxis. Although plaque is the most likely source of a bacteraemia, repeated sampling over a period of a few weeks would disturb the ecology of a site and introduce variations in the flora that might be indistinguishable from those induced by the antibiotic. The tongue is a major source of salivary bacteria (Marsh and Martin, 1984) but the recovery of organisms such as $S$. mutans and $S$. sanguis, for which the teeth are the main habitat, implied that our stimulated saliva samples included species representative of plaque.

Small numbers of amoxycillin-resistant streptococci were found in all of our volunteers before treatment, none of whom had recently received antibiotics. However, the majority of such bacteria would have been killed by the peak serum levels of amoxycillin and, therefore, would be unlikely to pose a threat to patients susceptible to infective endocarditis. It is generally assumed that all oral streptococci are highly sensitive to the penicillins. However, in addition to our study, several other groups have reported the carriage of small numbers of resistant streptococci in the oral cavity of healthy subjects (Drucker and Jolly, 1971; Sukchotiratana, Linton and Fletcher, 1975; Phillips et al., 1976), while the numbers of such bacteria are greater in people exposed more frequently to antibiotics such as those at risk of infective endocarditis (Phillips et al., 1976; Shanson and Namnyak, 1982).

Within $5 \mathrm{~h}$ of administration, amoxycillin reduced the numbers of anaerobic salivary bacteria and streptococci. The antibiotic also reduced numbers of bacteria resistant to amoxycillin $2 \mathrm{mg} / \mathrm{L}$ and, surprisingly, the few organisms isolated that were resistant to $40 \mathrm{mg} / \mathrm{L}$. Either a very high concentration of amoxycillin was entering the mouth or, as is more likely, the antibiotic was having a transient bacteriostatic effect and the organisms, unable to multiply, were lost from the mouth by swallowing. The finding of little or no long-term effect of a single 3-g dose of amoxycillin on the numbers of resistant streptococci was in agreement with that of a previous study (Oakley et al., 1981). However, subsequent doses resulted in a significant rise in the numbers of resistant bacteria which is consistent with the results of a recent study with repeated, two-dose amoxycillin prophylaxis (Southall et al., 1983). As the first dose of amoxycillin did not significantly increase numbers of resistant streptococci, it is arguable that a second prophylactic dose of antibiotic would not be invalidated. Furthermore, the increase in numbers of resistant bacteria after subsequent doses might well take place after the at-risk period which occurs immediately after dental treatment. More samples taken during this critical time would have been necessary to resolve this point. The third dose of amoxycillin caused an even greater rise in the numbers of resistant bacteria. However, as stated earlier, only those organisms resistant to amoxycillin $40 \mathrm{mg} / \mathrm{L}$ would be expected to pose a threat to the patient and the numbers of these bacteria are so low (in our study the range was $0-5.82 \times 10^{4} \mathrm{cfu} / \mathrm{ml}$ of saliva) that they would probably fall below the likely infective dose. The critical inoculum size for induction of infective endocarditis in man cannot be determined. In rabbits an infective dose of $10^{8} \mathrm{cfu}$ of $S$. sanguis was required to produce endocarditis 
consistently (McGowan et al., 1983), while the numbers encountered in bacteraemia in man are c. $2.5 \times 10^{5} \mathrm{cfu} / \mathrm{ml}$ (Shanson, 1982).

The results of this study suggest that in patients at risk of infective endocarditis a second prophylactic dose of amoxycillin would not be invalidated if administered one week after the first dose. However, for at-risk patients requiring repeated dental procedures likely to result in bacteraemia, either alternative antibiotic regimens should be used each time or intervals of at least 4 weeks should be left between treatment sessions. This interval should be regarded as the minimum as two of our volunteers harboured resistant bacteria at higher than base-line levels for up to 7 weeks. Similar results were obtained in a study of the response of oral streptococci to a repeated, two-dose prophylaxis with amoxycillin (Southall et al., 1983), although in one of their subjects resistant bacteria persisted even longer, for 9-13 weeks. Further work will be necessary to determine whether the time interval between treatment with similar antibiotics should be extended as has been suggested previously (Shanson, 1982).

We thank the volunteers who participated in this study, and Bencard for the provision of the Amoxil ${ }^{\circledR}$ and placebo sachets, and for their financial support.

\section{REFERENCES}

British Society for Antimicrobial Chemotherapy. 1982 The antibiotic prophylaxis of infective endocarditis. Lancet 2:1323-1326.

Cawson R A 1981 Infective endocarditis as a complication of dental treatment. British Dental Journal 151:409-414.

Cawson R A 1983 The antibiotic prophylaxis of infective endocarditis. British Dental Journal 154:183-184.

Durack D T, Petersdorf R G 1973 Chemotherapy of experimental streptococcal endocarditis. I. Comparison of commonly recommended prophylactic regimens. Journal of Clinical Investigation 52:592-598.

Drucker D B, Jolly M 1971 Sensitivity of oral micro-organisms to antibiotics. British Dental Journal 131:442-444.

Hardie J M, Bowden G H 1976 Physiological classification of oral viridans streptococci. Journal of Dental Research 55:A166-A176.

Holbrook W P, Willey R F, Shaw T R D 1983 Prophylaxis of infective endocarditis. Problems in practice. British Dental Journal 154:36-39.

Lowes J A, Williams G, Tabaqchali S, Hill I M, Hamer J, Houang E, Shaw E J, Rees G M 1980 10 years of infective endocarditis at St Bartholomew's Hospital: Analysis of clinical features and treatment in relation to prognosis and mortality. Lancet 1:133-136.

Marsh P D, Martin M V 1984 Oral microbiology, 2nd edn. Van Nostrand Reinhold, Wokingham, pp 28-31.

McGowan D A, Nair S, MacFarlane T W, MacKenzie D 1983 Prophylaxis of experimental endocarditis in rabbits using one or two doses of amoxycillin. British Dental Journal 155:88-90.

Moulsdale M T, Eykyn S J, Phillips I 1980 Infective endocarditis 1970-1979. A study of culture-positive cases in St Thomas's Hospital. Quarterly Journal of Medicine 49:315-328.

Oakley C M, Darrell J A 1982 Prevention of infective endocarditis in the 1980's. In: Cawson R (ed) The nature and prevention of bacterial endocarditis. Medicine Publishing Foundation, Oxford, pp 35-38.

Oakley C M, Perez G, Darrell J H 1981 Single dose oral amoxycillin for prophylaxis of bacteraemia associated with dental surgery. British Heart Journal 54:343.

Pelletier L L, Durack D T, Petersdorf R G 1975 Chemotherapy of experimental streptococcal endocarditis. IV: Further observations on prophylaxis. Journal of Clinical Investigation 56:319-330. 
Phillips I, Warren C, Harrison J M, Sharples P, Ball L C, Parker M T 1976 Antibiotic susceptibilities of streptococci from the mouth and blood of patients treated with penicillin or lincomycin and clindamycin. Journal of Medical Microbiology 9:393-404.

Shanson D C 1982 The microbiology of infective endocarditis and its prevention. In: Cawson R (ed) The nature and prevention of bacterial endocarditis. Medicine Publishing Foundation, Oxford, pp 23-33.

Shanson D C, Ashford R F U, Singh J 1980 High-dose oral amoxycillin for preventing endocarditis. British Medical Journal 280:446.

Shanson D C, Namnyak S. 1982 Viridans streptococci with reduced bactericidal susceptibility to penicillin from patients with endocarditis: susceptibilities to erythromycin, rifampicin, vancomycin and aminoglycosides. In: Periti P, Grassi G G (eds) Current chemotherapy and immunotherapy. American Society of Microbiology, Washington D.C., pp 311-313.

Southall P J, Mahy N J, Davies R M, Speller D C E 1983 Resistance in oral streptococci after repeated two-dose amoxycillin prophylaxis. Journal of Antimicrobial Chemotherapy 12:141-146.

Sukchotiratana M, Linton A H, Fletcher J P 1975 Antibiotics and the oral streptococci of man. Journal of Applied Bacteriology 38:277-294.

Tozer R A, Boutflower S, Gillespie W A 1966. Antibiotics for prevention of bacterial endocarditis during dental treatment. Lancet 1:686-688. 